\title{
Distribution Model of Particulate Dust From Chimney of Sidoarjo Sugar Factory
}

\author{
S Syahrorini ${ }^{1}$, A Rahmansyah $^{2}$, Soemarno 3 , S H Pramono ${ }^{2}$ \\ ${ }^{1}$ Study Program Electro Engineering, Universitas Muhammadiyah Sidoarjo, Indonesia \\ ${ }^{2}$ Faculty of Engineering, University of Brawijaya, Malang, Indonesia \\ ${ }^{3}$ Faculty of Agriculture, University of Brawijaya, Malang, Indonesia
}

\begin{abstract}
Sugar factories in Indonesia are mostly built during the colonial era and therefore are not equipped with suitable environmental management equipment One of the effects of this activity is air pollution in the form of particulate matter from bagasse burning for energy. This study aims to determine the particle distribution of sterile emissions from the Sidoarjo Sugar Factory. The measurement of the sampling point with degradable dust collectors SNI 13-4703-1998 has been revised. The measuring point is scattered around the location of the sugar mill with a certain distance from the center of the chimney. The measurements are carried out for 24 hours at six-hour intervals so that the measurements at each sampling point are four times as long. The results of the particle dust measurements were analyzed by gravimetric method to obtain the particle dust concentration. Computer simulations are presented in the form of contour maps and 3D surface contours from particle dust concentrations. The simulation results show differences in the contour pattern and 3D surface contour due to differences in particle concentration for each measurement period. Each measurement period is also affected by wind speed and direction as well as measuring time by day or night.
\end{abstract}

Keywords: Contour, Dust Faal Collector, Distribution Model, Particulate, Surface

\section{INTRODUCTION}

One of the most important environmental components of human life is air. Therefore, the air quality must be preserved to support living things. The deterioration of air quality can be caused by various pollutants, including industries, power plants and motor vehicles. The biggest proponents of the decline in air quality are industrial chimneys and vehicle vapors. Industries that use fuel from coal, bagasse or other industries with chimney emissions are not moving. The chimney does not move to emit smoke when incomplete combustion occurs. Incineration of waste causes the decline of air quality in the environment $[1,2,3]$.

Air pollution can threaten the survival of living things, especially the comfort, peace and quiet of human life. Air pollution from long-term accumulation of motor vehicles that people inhale can lead to shortness of breath $[1,4,5]$. Air pollution caused by particles exceeding quality standards can cause health problems, especially in the physiological functions of human organs such as the lungs and blood vessels. Particles can cause chronic respiratory diseases such as

\footnotetext{
Correspondence address:

S. Syahrorini

Email : syahrorini@umsida..ac.id

Address : Doctoral Program Environmental Science, Brawijaya University, Malang
}

chronic bronchitis, bronchial asthma, lung cancer and pulmonary embolism $[1,4,5]$.Definition of air pollution based on Decree of the Minister of Health of the Republic of Indonesia No 1407 of 2002 on guidelines for the control of air pollution, ie air pollution is the process of import of foreign matter, energy or other components into the air due to human activities, to a degree, its affects human health [6].

Air pollution is influenced by the type of emissions emitted, the atmospheric conditions and the topography of the polluted area. The spread of pollutants is affected by the stability of the atmosphere, the more stable, the less favorable the receptor, because the concentration of the spread is higher. Wind speed also plays an important role in particle distribution, while high winds accelerate the process of particle dispersion. Topographical conditions influence meteorological conditions, meteorological conditions influence particle scattering patterns $[2,3,4,5,6,7]$.

In the simulation results of the $\mathrm{CO} 2$ deployment in the city of Semarang with the particle distribution pattern obtained by the LADM software, the $\mathrm{CO} 2$ distribution pattern can be determined from the topographical form with changes in the wind and sea breeze [8].

The dispersion calculation data source (Gauss) of airborne pollutant point analysis using 
air pollutant dispersion analysis and surfing mapping 10 achieved the highest concentration of NO 2, SO 2, CO and dust concentration closest to the pollutant source of the chimney industry [4]. In the analysis of air pollutant dispersion with the caline4 program and the surfer, the difference in $\mathrm{CO}$ concentration up and down is also caused by the meteorological factor wind direction and wind speed $[9,10,11]$.

Based on the proposed problems, it is necessary to conduct studies to find out the pattern of particulate emission propagation of chimneys in sugar mills. This insert pattern uses a computer simulation with Surfer 9 to determine the spread of stack emission particles around the sugar factory [12]. Ambient air measurements using standard SNI 13-4703-1998 Dust Extractors [13]. The purpose of this study is to determine the pattern of particulate particulate matter spread in sugar factories as a result of air pollution on the Community around the location of the sugar factory.

\section{MATERIAL AND METHOD}

\section{Study Site}

This research was done in Sidoarjo Sugar Factory Jl. Raya Candi No. 10 Sidoarjo. The sampling point for the particle measurement is 20 sampling points in the area of the sugar factory. In two villages, Candi Sayang and Soban Lor, 20 sampling points are distributed. The particle measurements in this study used a revised SNI 13-4703-1998 dust collector standard [13]. The measurement results were analyzed in the laboratory of the Faculty of Health of the University of Muhammadiyah Sidoarjo using the Gravimitri method to obtain a particle concentration [13]. Measurements at 20 sampling points around the sugar factory at 24hour intervals. Measurement I Hour 10: 00-16: 00, Measurement II Hours 16: 00-22: 00, Measurement III Hours 22: 00-04: 00, IV Measurement is from 04:00 to 10:00. Figure 1 shows 20 measurement points collected at the Candi sugar factory in Candi Sayang Village and Soban Lor Village.

\section{Data Collection}

Twenty sampling points were then measured by the distance of each point from the center of the chimney of the sugar factory to the sampling. Measurement of the distance of the measuring point by means of googlearth to determine the coordinates of the measuring point The measuring point is usually the dominant direction of the wind direction at the beginning of the measurement, namely Candi Sayang Village with the dominant wind direction west of the chimney sugar factory. The southern direction of the sugar factory is the Village Meeting Hall, the Mutiara Raya Housing and the Great Mosque of the temple, and the eastern direction of the sugar refinery Saban Lor Road Kedungpeluk.

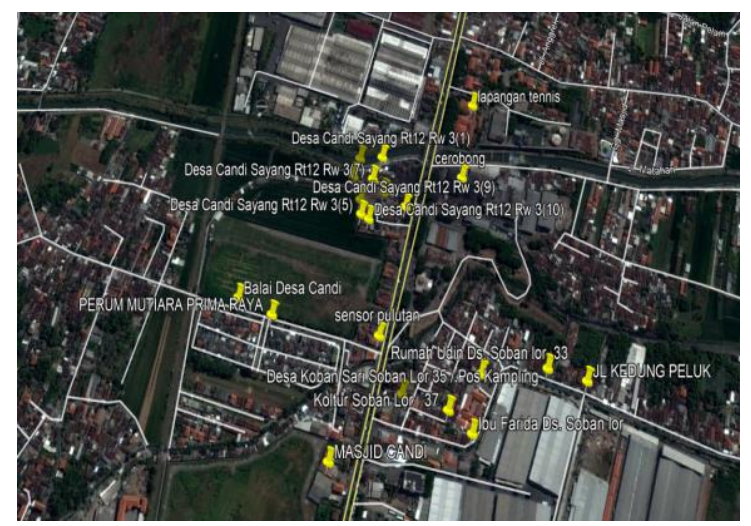

Figure 1. Reseach Location

The collection of data from the 24-hour readings with the sample changes four times to measure a six-hour interval. Total sampling of 80 samples of the particle measurement results. Chemical analysis using the gravimitri method was carried out from 80 particle samples so that the particle concentration was obtained from the measurements I, II, III and IV in Table 1 [13].

\section{Data Analysis}

Coordinate of Sampling Point ff the 20 measuring points, the determination of the coordinate points of the cropped googlemap in Autocad is carried out with the coordinate center (0.0) in the middle of the sugar mill chimney. So you get the coordinate point from every point of the research site.

From the coordinate point of each research location and calculation result of the particle concentration with Gravimitri method then computer simulation with Surfer 9 software $[12,13]$. The first step is to enter the coordinate value of the sample point and the particle concentration of each measurement. There are four sample measurements, ie from 10:00 to $16: 00,16: 00$ to $22: 00,22: 00$ to $04: 00$ and $04: 00$ to 10:00. Coordinate data and measurement results are entered into the worksheet, where column $A$ represents the $X$ coordinates, column $B$ represents the $Y$ coordinates, and column $C$ shows the concentration of the measured results. 


\begin{tabular}{|c|c|c|c|c|}
\hline $\begin{array}{l}\text { LOCATION } \\
(\mathrm{m})\end{array}$ & Dt (g/m²/Hours) & $\mathrm{Dt}\left(\mathrm{g} / \mathrm{m}^{2} /\right.$ Hours $)$ & Dt (g/m²/Hours) & Dt (g/m²/Hours) \\
\hline 154.81 & 266.2435529 & 80.6501208 & 142.4818801 & 2947.192075 \\
\hline 208.80 & 146.958807 & 21.76844369 & 204.6244613 & 51.04023872 \\
\hline 166.21 & 295.7716398 & 211.1408166 & 2019.034059 & 130.872407 \\
\hline 56160 & 93.57377099 & 893.9130698 & 217.2481956 & 124.3015215 \\
\hline 168.96 & 261.744814 & 32.60904141 & 220.8471868 & 205.7423298 \\
\hline 209.19 & 165.7717155 & 95.99491052 & 1185.704007 & 215.3941698 \\
\hline 434.60 & 2776.948886 & 215.3941698 & 380.756909 & 124.3287866 \\
\hline 473.95 & 146.8633792 & $220, .1655597$ & 136.3254239 & 31.40937767 \\
\hline 167.35 & 187142.6888 & 132.2356612 & 64.12747942 & 124.765028 \\
\hline 152.07 & 253.8379394 & 163.1815324 & 61.18285026 & 97.17276218 \\
\hline 321.98 & 226.3002037 & 115.3858388 & 29.3917614 & 5359.797632 \\
\hline 587.33 & 253.8379394 & 87.51001613 & 272.5417875 & 220.1655597 \\
\hline 473.95 & 5359.797632 & 146.8633792 & 146.8633792 & 40.07967464 \\
\hline 413.51 & 6.543620349 & 209.8320925 & 179.6223786 & 10.79697358 \\
\hline 156.73 & 240.8052288 & 139.0519324 & 209.8320925 & 98.42695608 \\
\hline 148.94 & 222.4830919 & 223.3010444 & 223.3010444 & 14511.45967 \\
\hline 172.96 & 159.5552762 & 93.57377099 & 316.7112249 & 146.8633792 \\
\hline 402.30 & 209.8320925 & 5359.797632 & 93.57377099 & 209.8320925 \\
\hline 617.61 & 163.5905087 & 165.7717155 & 5359.797632 & 223.3010444 \\
\hline 548.18 & 223.3010444 & 141.7784409 & 26.99243394 & 93.57377099 \\
\hline
\end{tabular}

Table .2. Coordinate $X$ and $Y$ From Distance Points Sampling

\begin{tabular}{ccc}
\hline LOCATION $(\mathrm{m})$ & Coordinate $X$ & Coordinate $Y$ \\
\hline 154.81 & -152.9563 & 23.8965 \\
208.80 & -208.2455 & 15.2229 \\
166.21 & -65.7042 & 12.9601 \\
56160 & 416.3639 & -376.8758 \\
168.96 & -167.3606 & 18.1596 \\
209.19 & -209.1723 & 2.8211 \\
434.60 & 237.3566 & -337.8561 \\
473.95 & -226.7761 & -416.1844 \\
167.35 & -166.3606 & 18.1596 \\
152.07 & -144.5337 & 27.6042 \\
321.98 & -175.0810 & -270.2180 \\
587.33 & 442.4951 & -386.2086 \\
473.95 & -226.7761 & -416.1844 \\
413.51 & -347.1256 & -224.7096 \\
156.73 & -155.8038 & 17.0113 \\
148.94 & -145.8154 & 30.3534 \\
172.96 & -172.8918 & 4.8974 \\
402.30 & 241.8146 & -321.5153 \\
617.61 & 475.2338 & -394.4558 \\
548.18 & 403.8686 & -370.6635 \\
\hline
\end{tabular}

After the datasheet has been inserted, it is stored in extensen dat, txt and grid. Then continue the grid data process with extensen.dat data by selecting Linear, Gaussian, Exponent, and Logarithm. The data validation is performed to process the Kringing data. All new processes have opened the grid data process to generate various types of maps, including outline maps, vector maps, classsedpost, postmap, 3D surfaces, and 3D wireframe.

From the coordinate point of each research station and the calculation result of the particle concentration with Gravimitri method then computer simulation with Surfer 9 software $[5,7,8,9,10,11,12,13]$.

\section{RESULT AND DISCUSSION}

Based on Table 1 and Table 2 of the concentration of each measurement sample and coordinate point, we obtain contour and Clossedpost maps. Figure 2: Describes the card contours and classroom measurement I of the measurement result I from the concentration value in five intervals, namely 261.7448-187200, 226.3002-261.7448, 209.8352-226.3002, 146.9588-209.8352 and 0-146.9588. The largest 
concentration interval is 261.7448-187200 exactly in the position of Candi Sayang Village, Candi Village Hall and Prima Raya Pearl Housing. Three areas of measurement sampling location in accordance with the wind direction during the measurement, ie west of the chimney Sugar Factory. The results of this measurement show that the pattern of particle dispersion from the largest sugar factory fireplaces affects the community around Candi Sayang Village, Candi Village Hall and Prima Raya Mutiara Housing. In accordance with the wind direction of the measurement, the dispersion pattern follows the dominant wind direction [15].

As is apparent from Table 1 and Table 2 of Measurement II, it is known that the concentrations in quadrants I, III and IV differ from the center of the chimney. Figure 3 . Explanation of map contours and Classedpost measurement II with the largest concentration interval 215.339-5360 is located in Quadrant IV, ie the sampling is in the Southern Chimney Sugar Factory, located exactly in Kedungpeluk Village. This is because the direction of the land breeze changes in sea breezes since the measurement time is between 4:00 pm and 10:00 pm $[15,16,17,18,19]$.

From the table of sampling distance and the coordinates of Table 1 and Table 2 of Measurement III it is known that the concentrations in quadrants I, II, III and IV differ from the center of the chimney. Figure 4. Exploration of the map contours AND Classedpost measurement III with the largest concentration interval 316,7112-5360 in quadrants II and IV is the measurement sampling area in the Western and Southern Chimney Sugar Factory. Located in the village of Candi Sayang and Kedungpeluk Village. This is influenced by the wind direction from west to east, since the measuring time is $22: 00$ to $04: 00$. There is a change in sea and land breezes also affecting topography of the Sidoarjo region, which is delta region.

Based on Table 1 and Table 2 of the IV measurement, the concentration extends in quadrants I, II, III and IV of the chimney center. Figure 5. Explaining map contours and Classedpost measurements IV with the largest concentration interval is 220.1656-14520 in quadrants II, III, and IV, the measurement area west of the chimney, south, and southeastern chimney sugar factory. The location is in Saban Lor Road Kedungpeluk. This is due to changes in wind direction east due to the measurement time at 04: 00-10: 00 [20,21,22,23,24,25]

Of the four contoured and classified map images, each measurement shows the highest concentration difference in the quadrant from the center of the chimney of the sugar factory. At measurement $\mathrm{I}$, the highest concentration is in Quadran II, the measurement area in the village of Candi Sayang. The measurements are carried out from 10 to 16 o'clock with wind direction to the west. The highest particle concentration is 100,000 with intervals of 10,000 . The largest concentration measurement $\|$ is located in quadrants I and IV, exactly in the villages of Candi Sayang and Kedungpeluk Village. This is because the wind direction changes from 4:00 am to 10:00 pm. The highest particle concentration in Measurement II is 4,000 with intervals of 500

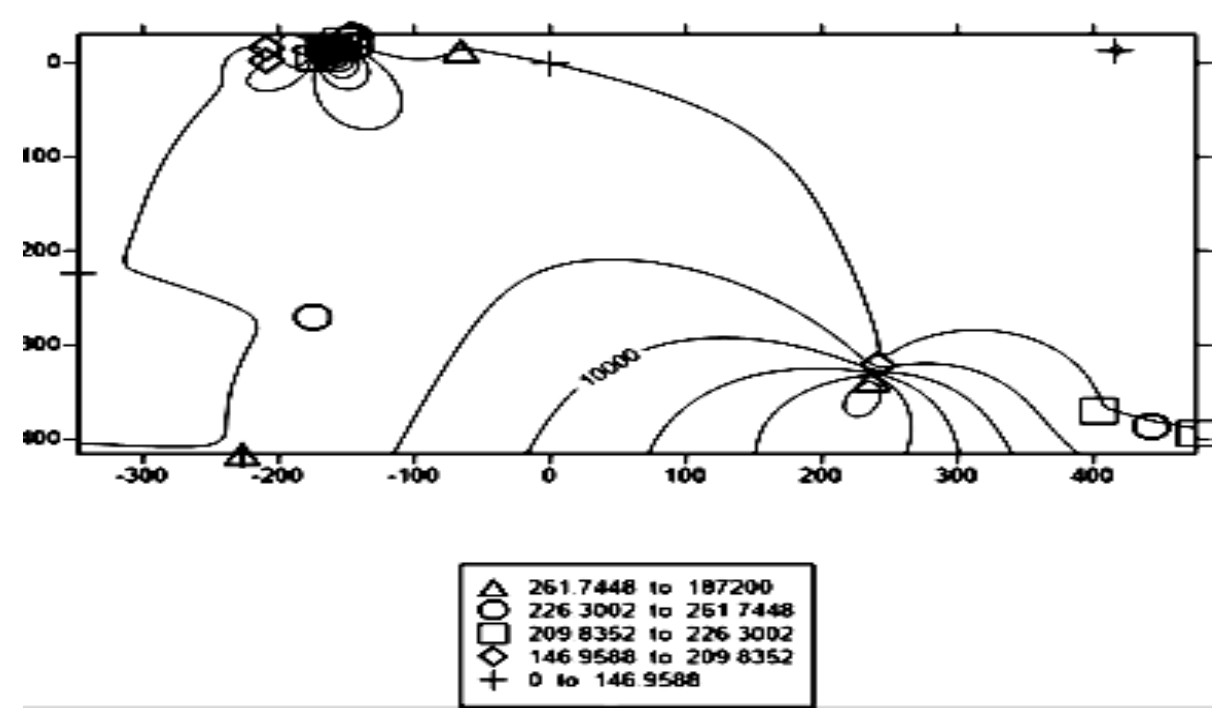

Figure 2. Map Contours AND Classedpost Measurement I 


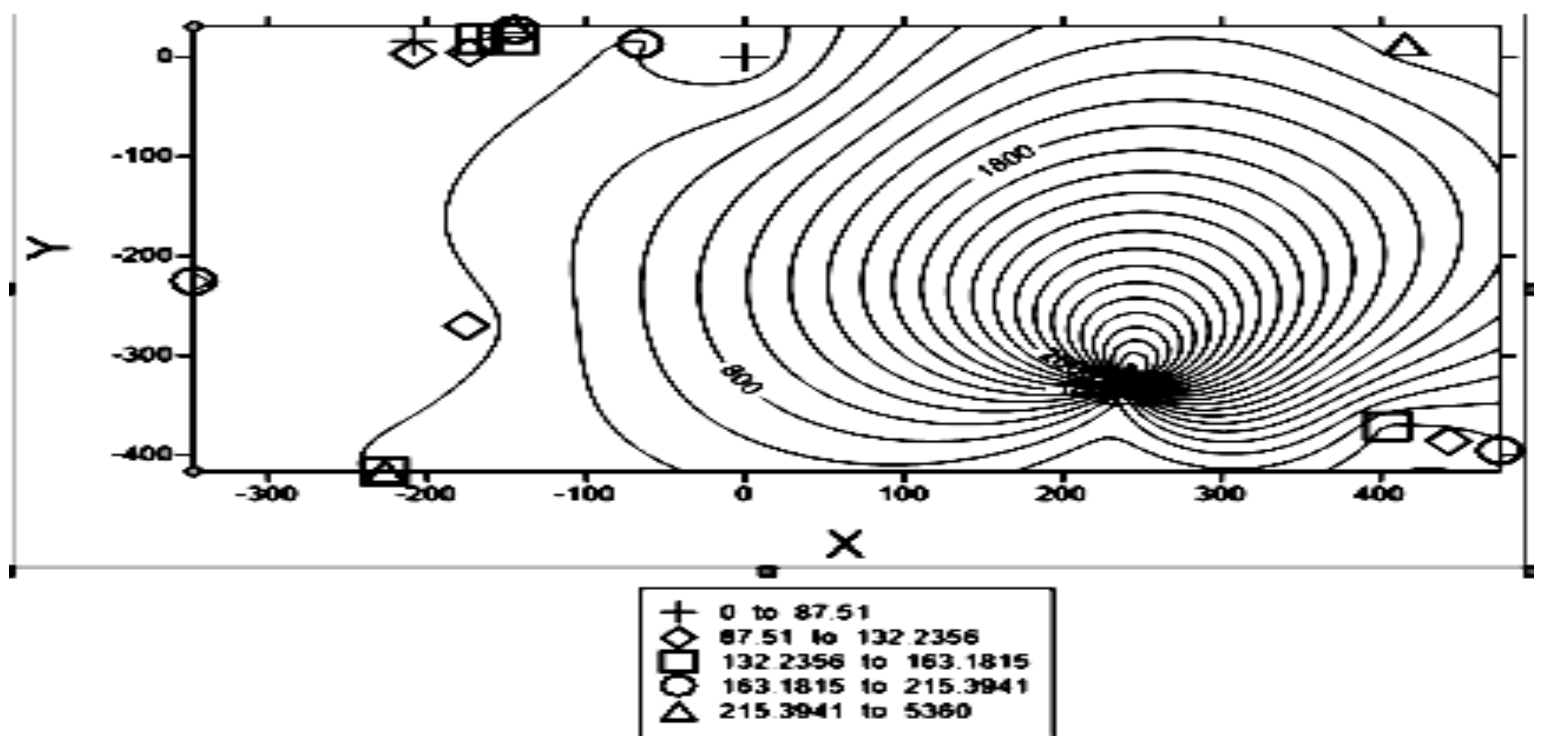

Figure 3. Map Contours AND Classedpost Measurement II
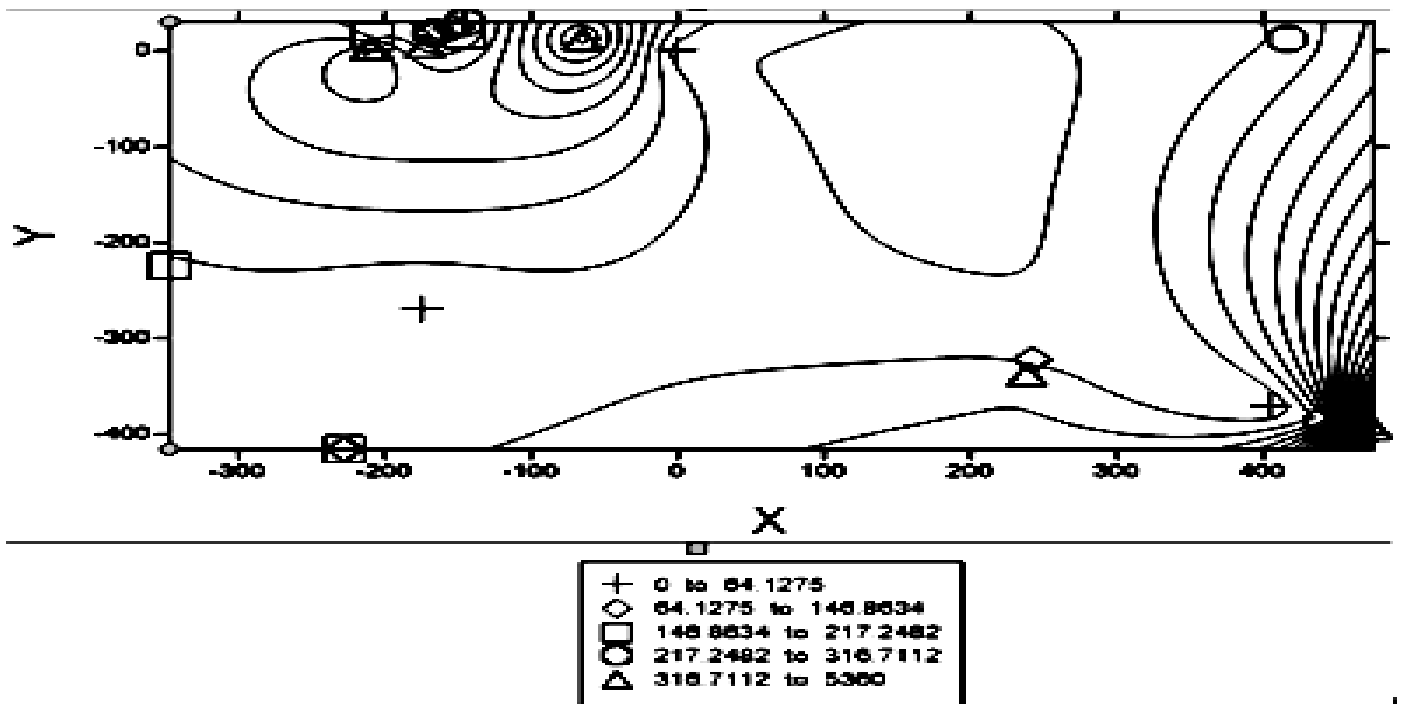

Figure 4. Map Contours AND Classedpost Measurement III

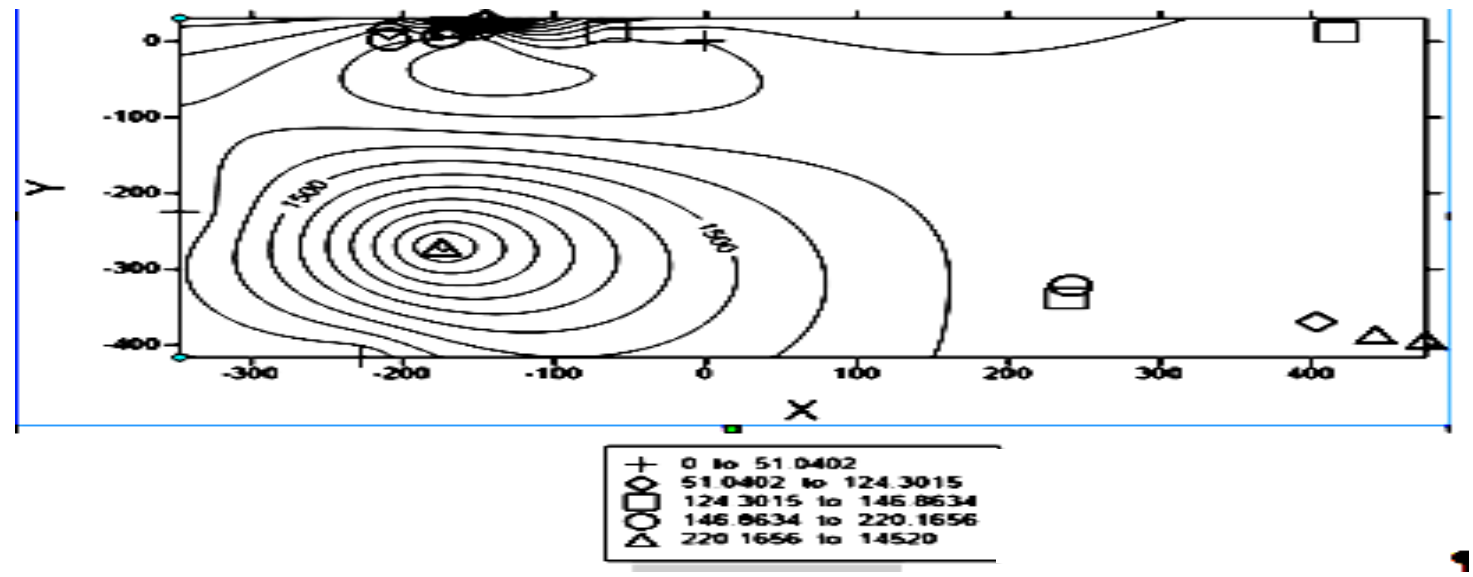

Figure 5. Map Contours AND Classedpost Measurement IV 
concentration levels. Measurements III of particle propagation were distributed across quadrants I, II, III and IV. However, the highest concentration in the IV quadrant is the Kedungpeluk village, the highest concentration of 4,000 at 500 intervals, occurring at night until early in the morning, ie from 22.00-04.00 clock, is measured. This is the effect of the wind direction change from the wind direction from wind to sea wind.

In the dispersion pattern of dust particles of these sugar mills, there are four patterns of particulate dust dispersion according to the measuring time interval. The four particle dust scattering patterns are influenced by the wind direction during the measurement, the wind speed and the topography of the study area. Based on the measurements $I$ in Figures 2 and 6 of the dust particle dispersion pattern with the highest concentration of 100,000 in Quadrant II is located in the village of Candi Sayang. From this measurement, the dispersion pattern of the particles spread along the quadrants II and IV, which means the dispersion of particulate dust from sugar mills at 10:00 to 16:00 west of mills of sugar mills. The distribution of dust particles from the largest sugar mills to the people living in Candi Sayang Village. Candi Sayang village lies west of the center of the chimney factory, in Candi Sayang Village there are 10 measuring points with a distance of 148.94-208,08 $\mathrm{m}$ from the center of the chimney. This distance is the shortest distance to the center of the chimney and lies west of the chimney, depending on wind speed and wind direction, when the measurement is westbound. According to the shortest distance of the chimney, the wind speed and the prevailing wind direction in the west, Candi Sayang Village is exposed to the largest dust spread [11,21,22,23,24,25,26,27,28,29].

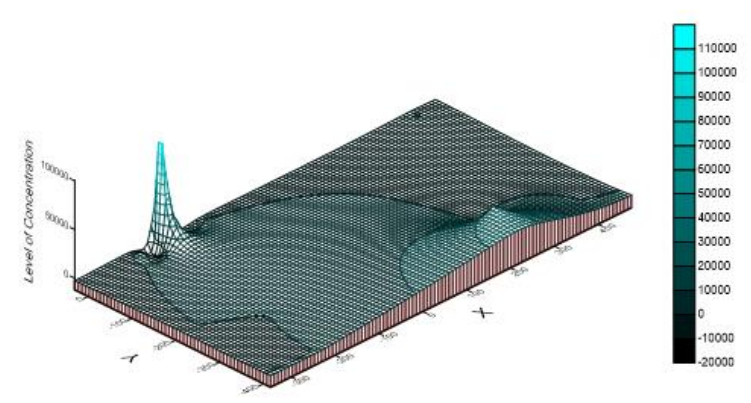

Figure 6. 3D Wireframe Measurement I

Based on the measurement results II in Fig. 3 and 7 , the pattern of dispersion of dust particles from sugar mills $16.00-22.00$ clock changes the measuring time from evening to night, ie changes in wind direction from wind to sea wind. This change in wind direction affects the dust particle dispersion pattern from the center of the grinder mill factory of the sugar mill to the point of sampling. Distribution patterns distributed across quadrants I, III and IV. The highest concentration of particulate dispersion is in Kedungpeluk Village, southeast of the sugar factory with a concentration of 4,000 . This means that the largest dust load in the community around Kedungpeluk Village is from 16:00-22:00.

From Figure 4 and Figure 8 on the III measurement from $10 \mathrm{pm}$ to $4 \mathrm{am}$, time changes from night to morning. This time change affects the particle scattering pattern of sugar mill dust, the change from sea breeze to wind breeze. The distribution pattern of particulate dust from sugar mills is evenly distributed across quadrants I, II, III and IV with the highest concentration of 4,000 Dikwadran IV exactly Kedungpeluk Village. The exposure to particulate matter is the highest concentration in the community living in Saban Lor Road Kedungpeluk Village at 10:00 pm to $4: 00$ am the entire time $[11,24,25,26,27]$.

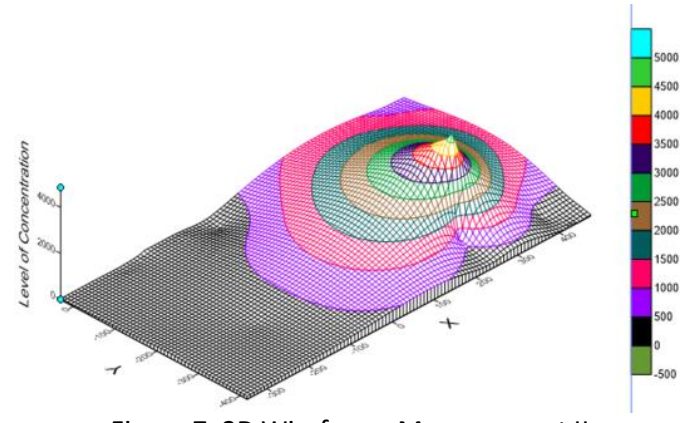

Figure 7. 3D Wireframe Measurement II

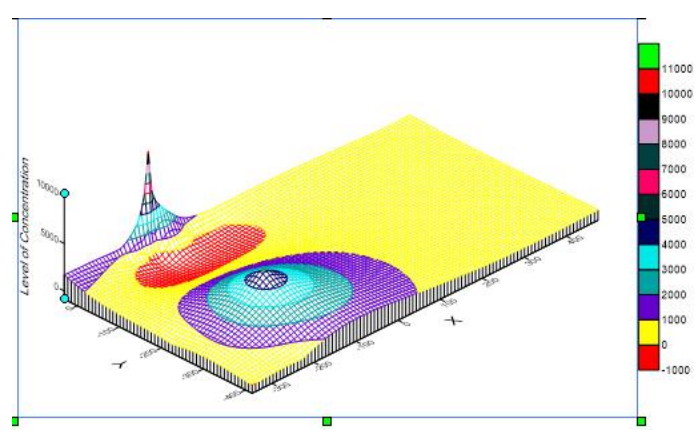

Figure 8. 3D Wireframe Measurement III

Based on Figure 5 and Figure 9 on the IV measurement from 4:00 to 10:00 no changes in the direction of the land and sea winds, but the dominant wind direction to the west. However, the particle scattering pattern is distributed across quadrants I, II, III and IV. The highest 
concentration level of the particle-dust distribution pattern in Candi Sayang Village is 10,000 . In the morning, the pattern of spreading dust particles from the sugar mill west of the center of the chimney, namely the particulate matter exposure of the largest sugar mill in the community around the Candi Sayang Village. In the morning, the dominant wind direction west of the center of the chimney, so the largest particle spread to Candi Sayang Village west of the chimney center leads $[10,11,28,29]$

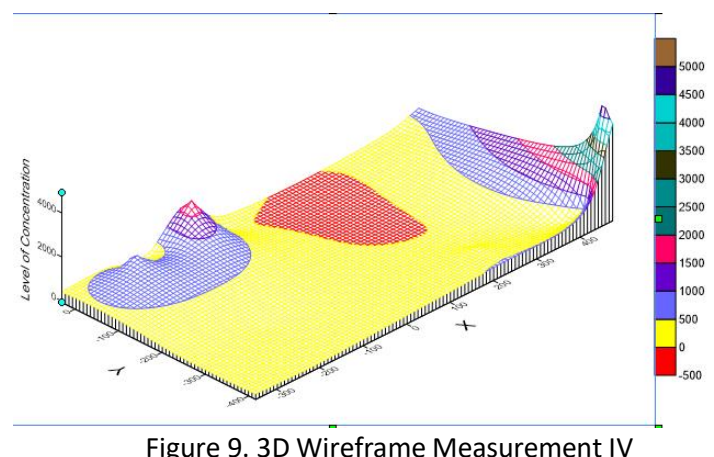

The distribution pattern of the dust particles in the sugar mills is also influenced by the high chimneys of the sugar mills and the speed of spraying the water on the kettle. The higher the chimney, the lower the concentration level of the spread. And the faster the spray rate of the water in the boiler, the less the particulate dust falling from the center of the sugar mill chimney to the sugar mill location concentrates on the spread of dust particles.

With the analysis of the particle dispersion using the surfer 9 , it can be determined that the wind direction affects the distribution of the concentration in the measurement point sampling area according to the analysis of each quadrant from the center of the sugar mill chimney. The measure I of the largest concentration is located in the Quadrant I, the measuring area west of the chimney of the sugar factory, more specifically Candi Sayang Village, from 10 to 16 clock with the wind direction to the west. Measurement II is the largest concentration in quadrants I and IV, exactly in the village of Candi Sayang and Kesa Kedungpeluk. There was a change in the wind direction at 4:00 to 22:00. Influence of wind direction changes from the wind direction to the sea wind. Measurement III of the particle-dust distribution pattern along quadrants I, II, III and IV, the largest concentration is Quadrant IV in Kedungpeluk Village. This measurement takes place at 22.00 to 04.00 , there is a change in direction of the sea breeze on land. Measurement IV of the particle dust spreading pattern along quadrants I, II, III and IV, the largest concentration is Quadrant I in Candi Sayang Village. This measurement takes place at 4:00 am to $10: 00 \mathrm{am}$, the morning of the prevailing wind direction to the west. The spreading of particulate dust can be used at the time of measuring the grinding season of the sugar mill to determine the pattern of particulate dust spreading around the area of the sugar factory. This propagation pattern corresponds to the topological, meteorological, wind speed and prevailing wind direction during the measurement. The largest particle dispersion lies in the nearest test sample with the center of the chimney factory of the sugar factory and in the direction of dominant wind and wind speed $[8,9,10,11,27,28,29]$.

According to the Aktrista A.I. P et al (2014) study, Surfer 10 for calculating the Gaussian dispersion of the overlay results shows the highest concentration near the pollutant source, ie the chimney [10]. There is a similarity in the highest concentration of concentrated dust particles at the next location to the center of the immovable chimney, which is the center of the chimney of the sugar factory in the village of Candi Sayang. However, there is a difference between the research site and the fuel burning boiler used in this study at the sugar mill chimney, which used bagasse fuel. Adequate research Diken Yus Damara and all (2017) with CALINE 4 and Surfer 8 states differences in the rise and fall in $\mathrm{CO}$ concentrations are also caused by meteorological factors, ie wind direction and wind speed [11]. The difference of this study with previous research, this research refers to particle dust from immobilized chimney sugar-based sugar mill in the generation of energy in boiler, earlier research of moving chimney on motor vehicle. In addition to the use of dust collectors fell SNI 13-4703-1998, which was revised to measure the particulate matter concentration [13]. The similarity of this research on the use of surfer program to know the pattern of pollutant diffusion, and the similarity of the influence of wind direction and meteorological factors in the pattern of pollutant propagation.

Based on computer simulation patterns of the surfer's use in the sugar season. The use of surfers is suitable because the particle scattering pattern is affected by the dominant wind direction. 
Periodic measurements are required both before milling, during milling, and after milling, by analyzing the particulate propagation patterns of chimney emissions from sugar mills. This is done to determine the effects of particle spread on people around sugar factories, especially at factory sites in the middle of densely populated cities.

\section{CONCLUSION}

Due to the implementation of collector dust SNI 13-4703-1998, which was revised, the result of dedusting SNI 13-4703-1998 could work optimally. Gravimetric analysis indicates there is a defect in the measurement, so the effect of the concentration of dust concentration from the sugar mill chimney. Surfer 9 computer simulations illustrate the distribution of dust particles in the Sidoarjo Sugar Factory, which distributes particulate matter dust below the ambient air standard, making it safe for people around Candi Sayang Village and Soban Lor Village. And the pattern of particle propagation according to the prevailing wind direction during the measurement.

\section{ACKNOWLEDGEMENT}

We acknowledged DIKTI, Universitas Muhammadiyah Sidoarjo and University of Brawijaya.

\section{REFERENCES}

[1]. Citra Ferdyan AIJ, Achmad Wijaya, Fitra Adi Kurniawan, 2006. Measuring Particulate Matter (PM10) In Motor Vehicle Disposal. Journal of Informatics volume 1 No. 6 December 2006

[2]. Q Jia, Yi Huang, Nadhir Al-Ansari, Sven Knutsson, 2014. Dust Emmision from Landfill Due to Deposito. Civil, Mining and Nature Resources Engineering of Luleå University of Technology.

[3]. Etty Yhulliarsih, Alexander Tunggul Sutan Haji, Bambang Rahadi Widiatmono, 2015. Dispersion Analysis of Particulate Load from Cement Industry in Tuban Regency by Using Spatial Aproach. Jurnal Sumberdaya Alam dan Lingkungan.

[4]. Inti Hestya, Corie Indria Inscription. Environmental Health Risk Factors Community Around Sugar Factory Rejo Agung Baru Madiun. Journal of Environmental Health, Volume 8 No. 1 January 2015, 81-91.
[5]. X. Wang, Y. Zhang, G. L. Riskowski, M. Ellis, 2002. Measurement and Analysis of Dust Spatial Distribution in a Mechanically Ventilated Pig Building. Biosystems Engineering (2002) $81 \quad(2), \quad 225 \mathrm{~d} 236$ doi:10.1006/bioe.2001.0014.

[6]. DepKes. Republic of Indonesia, 1993. Working Health Efforts In In Formal Sector In Indonesia Printed 2, Gunung Agung Jakarta.

[7]. D.B,Turner, 1970. " Work book of Atmospheric Difspersion Estimates. Environmental Protection Agency". Research Triangle, Nort Carolina.

[8]. Bohdan Kribek, Vladimír Majer, František Veselovský, Imasiku Nyambe, 2010. Discrimination of Lithogenic And Anthropogenic Sources Of Metals And Sulphur In Soils of The Central-Northern Part Of The Zambian Copperbelt Mining District: A Topsoil Vs. Subsurface Soil Concept. Journal of Geochemical Exploration 104 (2010) 69-86.

[9]. Sumarwati, Saiful Hamdi, Nurlaini, Dessy Gusnita, 2001. Simulation of CO2 Deployment in Semarang With LADM Software. Kontrubis Fisika Indonesia Volume 12 Number 2 April 2001

[10]. Aktrista Ayu Ika Permatasari, Dwi P. Sasongko, Imam Buchori, 2014. Analysis of Air Pollutant Dispersion Using Gauss Dispersion Model and Surfer Mapping 10. Journal of EKOSAINS | Vol. 6 | No. 3 | November 2014.

[11]. Diken Yus Damara, Irawan Wisnu Wardhana, Endro Sutrisno, 2017. Analysis of Carbon Monoxide (CO) Water Quality Impact Around JL. Youth Affected by Car Free Day Activity Using Caline4 And Surfer Program (Case Study: Semarang City). Journal of Environmental Engineering, Vol. 6, No. 1 (2017).

[12]. Surfer9. www.goldensoftware.com/ products/surfer

[13]. Determination of Air Dust Level With Dust Catcher Falling(Dust Fall Collector). sisni.bsn.go.id/index.php/sni_main/sni/deta il_sni/5147.

[14]. Januar Arif Fatkhurrahman, Ikha Rasti Juliasari, Nur Zen, 2016. Verification of Low Cost Particulate Sensor As A Particulate Sensor On Modified Wet Scubber Technology. Journal of Industrial Pollution Prevention Technology Research. 
[15]. Seigneur. C, 2001. Current Status of Quality Models for Particulate Matter. Jounarnal of The Air Waste Management Association, Pages: 1508-1521, Volume: 51, ISSUE.

[16]. Seinfield, H. J. 1975. Air Pollution Control, Physical and Chemical Fundamental. Mc. Graw-Hill. Inc. United States of America.

[17]. Prof. S. M. Kavishhwar, Prof. J. M. Chanchalani, Prof. S. P. Daf, 2014. Dispersion Mode; ing Of Hazardous Chemicals with Matlab Software in the View of Safety. IJMIT // Vol.2 Issue 10 // October // Page No. 761-767 // ISSN-2348-196x.

[18]. Holzbecher, E. (2007). Environmental Modeling using MATLAB R. Spinger-Verlag, Heidelberg

[19]. Febriandi Hasibuan, Warsito, Sri Wahyu Suciati, 2015. Model Simulation of Gas Pollutant and Molecular Particulate at Cement Plant Using Matlab Software 7.12. Journal of Theory and Applications of Physics. Volume 03, N0. 02, July 2015.

[20]. Atrisman Nukman, Abdul Rahman, Sonny Worouw, Moh. Ichsan Setiadi and Carolina Rusdy Akib, 2005. Risk Analysis and Risk Management of Air Pollution: Case Study In Nine Large Stripped Transpotation Cities. Journal of Health Ecology Volume 4 No. 2, August 2995: 270-289.

[21]. Chen, Tze Ming Gokhale, Janaki Shofer, Scott Khuschner, Ware G, 2007. Ourdoor Air Pollution: Particulate Matter Health Effects. The American Journal of The Medical Sciences. Pages: 235 - 243, Volume: 333, ISSUE: 4.

[22]. Djuraidah Anik, 2006. Estimation of SpatioTemporal Additive Model Using Linear Mixed Model Approuch with Application to Ozone Data in Surabaya. Proceeding of the First International Conference on Mathematics and Statistics, Bandung June 19-21, 2006 (to be published).

[23]. Mohamad yani, Ika Purwaningsih, Mas Nandang Munandar, 2012. Life Cycle Assessment of Sugar at Cane Sugar Plant. EJurnal Agribusiness Indonesia July 2012. Vol. 1 No. 1 P 60-67 ISSN: 2252-3324.

[24]. Randi Novirsa and Umar Fahmi Achmadi, 2012. PM2.5 Exposure Risk Analyzes In Ambient Air At Day Against Society In Industrial Area. Journal of Enviroment Healt Volume 7 No. 4, November 2012.

[25]. Richard Van de Broek, Ts Jalle Vanden Burg, Ad Van Wijk, Wim Turkenburg, 2000. Electricity Generation from Eucalyptus and
Bagase by Sugar Mills in Nicaragua: A Comporision With Fuel Oil Electricity Generation on The Basis of Coats, Macro Economic Impacts and Enviromental Emissions. Biomass \& Bioenergy. www. Elsevier. Com / located / biombioe.

[26]. Roberts, Steven Martin, Michael A, 2007. A Distribute Lag Approach to Fittings NonLinear Dose-Response Models in articulate Matter Air Pllution Time Series Investigation. Journal Environmental Research, Pages: 193 - 200, Volume: 104, ISSUE: 2.

[27]. Sri Suryani, Gunawan Ambo Upe, 2010. Model Distribution of SO2 Pollutants in the Chimney of PT. Semen Tonasa. Unhas congress and National Seminar of Coordination Body of Center for Environmental Studies Se-Indonesia to XX, 14-16 May 2010.

[28]. Surpiyono, 2010. Computer Applications For The Visualization of Gas Distribution Patterns From Instant Point Source In The Silent And Medium Anisotope Fluid. JFN, Vol 4 No. 1, May 2010 ISSN 1978-87

[29]. Nelly Sri Rahayu Simanjuntak, Ari Suwondo, Ida Wahyuni. Relationship Between Total Coal Dust and Inhalation And Individual Characteristics With Pulmonary Function Disorders In Workers At The Coal Yaed Power Plant PLTU X Jepara. Jurmal Public Health 2013, Volume 2 No. 2 April 2013. 